\title{
Lifelong Coprophagy in Male Mice
}

\author{
Koichi Y. EBINO, Tomio SUWA**, Yoshibumi KUWABARA** \\ Toru R. SAITO and Kazuaki W. TAKAHASHI*
}
Toxicology Division, Institute of Environmental Toxicology, Suzuki-cho 2-772,
Kodaira-shi Tokyo 187, Japan, *Department of Laboratory Animal Science, Nippon Veterinary and Zootechnical College, Kyonan-cho 1-7-1, Musashino-shi, Tokyo 180, and **Feed and Nutrition Research Laboratory, Oriental Yeast Co., Ltd., Azusawa 3-6-10, Itabashi-ku, Tokyo 174.

(Received 24 September 1986/Accepted 25 March 1987)

\begin{abstract}
Changes in coprophagy with age were investigated in male ICR mice during their life span. Sucklings showed coprophagy at 17 to 18 days old, i.e., a few days after they began to excrete feces autonomously. The number of fecal pellets ingested peaked at 5 to 6 weeks old (13 pellets/day) and gradually decreased, thereafter (2.1 pellets at 78 weeks old, 1.5 pellets at 104 weeks old). The diurnal pattern of coprophagy also changed with age. Growing mice showed vigorous coprophagous activity in both light and dark phases, whereas animals over 30 weeks old exhibited less activity in both phases, especially in the dark phase. Feces proved to be abundant in vitamin $B_{12}$ and folic acid throughout the life span. These results suggest that the frequency of coprophagy changes in association with the nutritional requirements of mice during the process of growth or aging.
\end{abstract}

\section{雄マウスに护ける coprophagy の生涯観察成績 \\ 海老野耕一 ·諏訪富男 $* *$. 桑原吉史 $* *$. 斎藤 徹 $\cdot$ 高橋和明 $*$ \\ (財)残留農薬研究所毒性部 \\ *日本獣医畜産大学実験動物学教室 \\ **オリエンタル酵母工業株式会社飼料研究所}

coprophagy (食粪) は多くの動物種で認められる行動 であるが, その生理学的意義に関する研究は専らウサギ $[4,5,9]$ およびラット $[1,2,6]$ を用いて行われてきた。 われわれはマウスにおける coprophagy を行動および栄 養生理の面から検討してきたが, てれまでに coprophagy が点灯後の $6 \sim 8$ 時間の間に高頻度に行われ [8], その 日内発現パターンは摂餌抢よび飲水行動のいずれとも同 調していないこと［7］を報告した。今回はこのような coprophagy の日内での変化とは別に，その生涯を通じ ての変化にも與味が持たれたので, マウスの coprophagy の発現時期および加㱓に伴う変化について調べた。同時 に糞の成分についても週秢を追って分析した。従来, 他 動物種に扔いては本報告のような長期間にわたる coprophagy の観察は行われていない。

哺育14日から18日㱓までは ICR 系マウスの雌雄を, 4 週秢から 104 週粭にかけては雄のみを使用した。飼育 
は温度 $24 \pm 1{ }^{\circ} \mathrm{C}$, 湿度 $55 \pm 5 \%$, 換気回数 15 回/時（オー ルフレッシュエアー方式), 人工照明時間14時間/日（午 前 5 時点灯，午後 7 時消灯）飞設定されたセミバリアー システムの動物室で行った。哺育仔はポリカーボネート 製透明ケージ（215W $\times 330 \mathrm{D} \times 180 \mathrm{H} \mathrm{mm} ）$ に雌雄卆 4 匹を母動物とともに収容した。4 週龄以降では約 100 匹 の動物をステンレス製金網ケージ $(310 \mathrm{~W} \times 440 \mathrm{D} \times 230$ $\mathrm{Hmm}$ ）に 10 匹ずつ収容し, coprophagy 観察時には
この中から 8 匹の動物を無作為に選びポリカーボネート 製透明ヶージ $(92 \mathrm{~W} \times 205 \mathrm{D} \times 127 \mathrm{H} \mathrm{mm})$ に個別収容し た。ただし，4〜10 週齢にかけては同一動物を使用し た。飼料にはオリエンタル醉母工業侏製固型飼料を用 い, 殺菌した井厅水とともに自由に摄取させた。

coprophagy は，哺育 14 月〜18日秢にかけての 5 日間 ならびに 4，5，6，8，10，30，52，78 および 104 週检 の各ステージではそれぞれ $2 \sim 4$ 日間にわたり連続して

Table 1. Frequency of coprophagy at different ages and number of feces excreted

\begin{tabular}{|c|c|c|c|c|c|c|c|c|c|}
\hline Weeks of age & 4 & 5 & 6 & 8 & 10 & 30 & 52 & 78 & 104 \\
\hline $\begin{array}{l}\text { Frequency of coprophagy } \\
\text { per mouse per day } \\
\quad(\text { Mean } \pm \text { Standard error) }\end{array}$ & $\begin{array}{r}11.5 \\
\pm 1.8\end{array}$ & $\begin{array}{r}13.0 \\
\pm 1.8\end{array}$ & $\begin{array}{r}12.9 \\
\pm 1.3\end{array}$ & $\begin{array}{r}11.0 \\
\pm 1.3\end{array}$ & $\begin{array}{r}8.6 \\
\pm 1.3\end{array}$ & $\begin{array}{r}4.3 \\
\pm 1.0\end{array}$ & $\begin{array}{r}5.0 \\
\pm 1.1\end{array}$ & $\begin{array}{r}2.1 \\
\pm 0.7\end{array}$ & $\begin{array}{r}1.5 \\
\pm 0.7\end{array}$ \\
\hline $\begin{array}{l}\text { No. of feces excreted* } \\
\text { per mouse per day } \\
\quad(\text { Mean } \pm \text { Standard error })\end{array}$ & $\begin{aligned} & 147 \\
\pm & 10.1\end{aligned}$ & - & - & - & $\begin{array}{l}106 \\
\pm 5.8\end{array}$ & $\begin{aligned} & 73 \\
\pm & 10.2\end{aligned}$ & $\begin{array}{l}44 \\
\pm 2.7\end{array}$ & $\begin{array}{l}50 \\
\pm 3.6\end{array}$ & $\begin{array}{c}46 \\
\pm 2.4\end{array}$ \\
\hline
\end{tabular}

*; Values exclude the number of feces ingested by coprophagy

- ; not examined

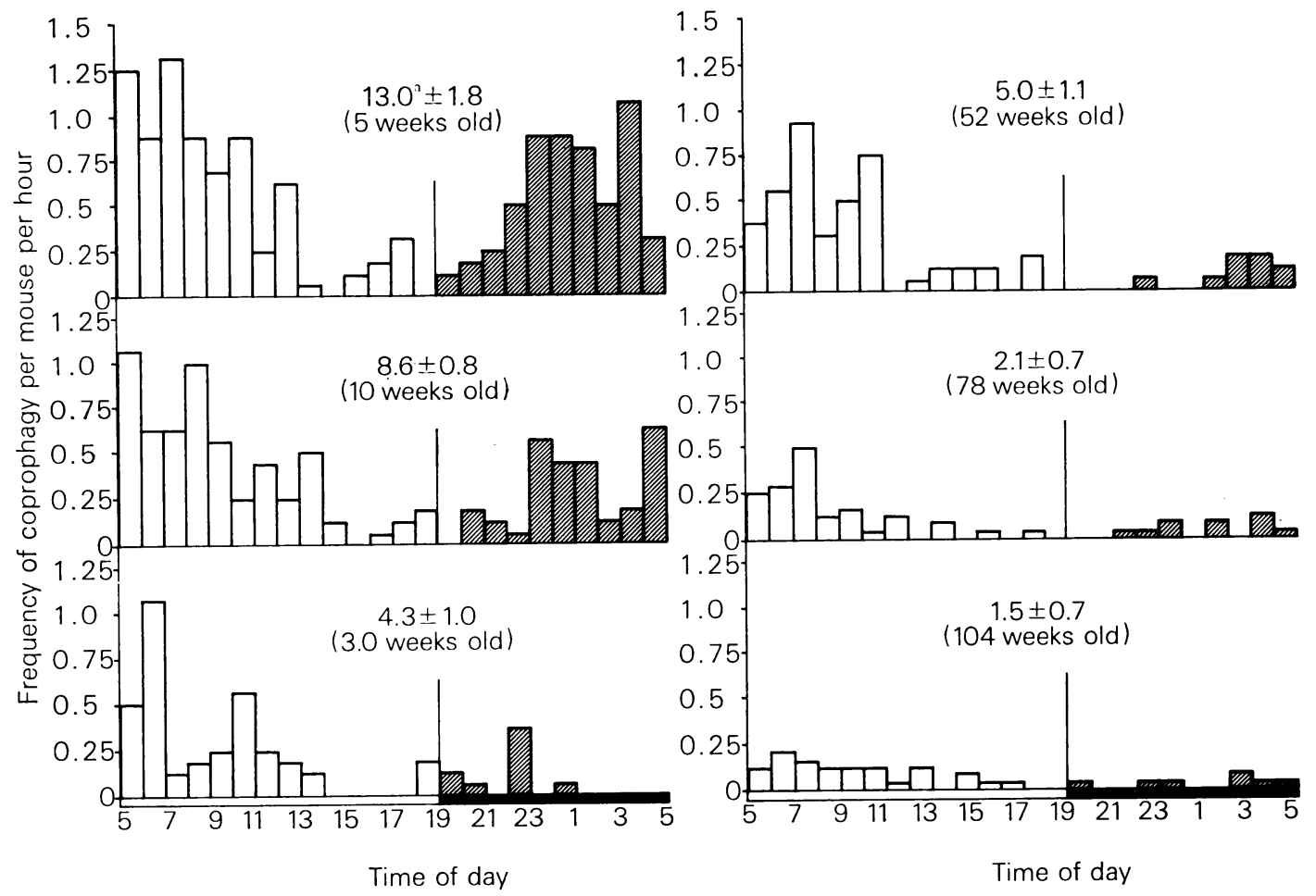

a: Mean frequency of coprophagy per day at corresponding age (with standard error) Each bar represents mean frequency of coprophagy of 8 mice (mean of 2 or 3 days).

Fig. 1. Diurnal pattern of coprophagy in male ICR mice at different weeks of age 
観察した。coprophagy の観察は, VTR により動物を 連続撮影し，後日録画テープを再生し観察する事によっ て行った。動物が 1 個の糞の半分以上を掑取した場合に coprophagy 1 回と記録した。暗期における撮影には赤 外線投炏機を利用した。また，26〜30，48～52 および 100 104 週秢䎲かけて，侮日午前 $7 \sim 11$ 將之个後 19 23時の間に排泄された粪をそれぞれ採取して $-30^{\circ} \mathrm{C} に て$ 保存し，後日成分の分析を行った。分析項目は Table 2 に示した。分析方法についてはすでに報告した $[3]$ 。

マウスに生後初めて coprophagy が観察されたのは, 17〜18日桻にかけてであった。まず肚門に顔を近づけて

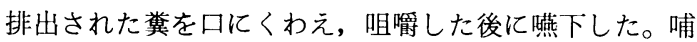
育仔の䔬がトレー上に認められたのが15日齢頃であった ことから，マウスに打ける coprophagy は自律的な算の 排泄開始後，2〜3 日以内に始まることが分かった。

4 週齢以降における 1 日 1 匹当りの coprophagy の頻
度を排粪数とともに Table 1 に示した。最も coprophagy の盛んな時期は 5 週榆で平均13個の粪を食べてい た。6 週秢においても12.9個と依然多いが，以後加齢に 従い漱減する傾向を示し 78 および 104 週秢ではそれぞれ 2.1 個抢よび 1.5 個之なった。幼若特の coprophagy の 活発な個体では，掑䬺しながら反射的に排泄される㓓を 次々に食べる場合も観察された。逆に高糩になると coprophagy を全く行なわなくなる日が增え始め，78週およ び 104 週齢ではそれぞれ 8 匹中 5 匹および 6 匹に，3 日 間の観察期間中に coprophagy を 1 度も行わない日が, 少なくとも 1 日は認められた。1 日当りの糞の排泄数は 幼若時ほど多い傾向にあったが，52週齢以降では安定し ていた。また総排泄数に対する coprophagy の割合は, 3. 2 10. $2 \%$ であった。一方, coprophagy の日内発現 パターンについて見ると，点灯後の $6 \sim 8$ 時間の間に coprophagy がしばしば行われ, さらにての時間帯で点

Table 2. Analysis of fecal constituents in male ICR mice

\begin{tabular}{|c|c|c|c|c|c|c|c|}
\hline \multirow[b]{2}{*}{ Constituent } & \multirow[b]{2}{*}{$\begin{array}{l}\text { Diet } \\
(\mathrm{MF})\end{array}$} & \multicolumn{2}{|c|}{$26 \sim 30$ weeks old } & \multicolumn{2}{|c|}{$48 \sim 52$ weeks old } & \multicolumn{2}{|c|}{$100 \sim 104$ weeks old } \\
\hline & & $\begin{array}{c}\text { Feces } \\
(0700-1100)^{*}\end{array}$ & $\begin{array}{c}\text { Feces } \\
(1900-2300)^{*}\end{array}$ & $\begin{array}{c}\text { Feces } \\
(0700-1100)^{*}\end{array}$ & $\begin{array}{c}\text { Feces } \\
(1900-2300)^{*}\end{array}$ & $\begin{array}{c}\text { Feces } \\
(0700-1100)^{*}\end{array}$ & $\begin{array}{c}\text { Feces } \\
(1900-2300)^{*}\end{array}$ \\
\hline \multicolumn{8}{|l|}{ Major components } \\
\hline Crude protein (g) & 26.19 & 22.87 & 18.07 & 22.96 & 21.78 & 23.32 & 20.95 \\
\hline Crude fat (g) & 6.18 & 2.58 & 2.85 & 2.75 & 2.95 & 2.70 & 2.76 \\
\hline Crude ash (g) & 6.88 & 21.29 & 22.09 & 20.24 & 19. 92 & 20.15 & 20.31 \\
\hline Crude fiber $(\mathrm{g})$ & 3.38 & 13.36 & 13.25 & 11.22 & 12.14 & 11.43 & 12.77 \\
\hline Nitrogen-free extract $(g)$ & 57.37 & 39.90 & 43.74 & 42.83 & 43.21 & 42.40 & 43.21 \\
\hline \multicolumn{8}{|l|}{ Inorganic elements } \\
\hline $\mathrm{Ca} \quad(\mathrm{g})$ & 1.23 & 5. 16 & 5.21 & 5.14 & 5. 12 & 5. 19 & 5.33 \\
\hline $\mathrm{P} \quad(\mathrm{g})$ & 0.90 & 3.76 & 3.88 & 3.56 & 3.47 & 3.59 & 3.57 \\
\hline $\mathrm{Mg}(\mathrm{g})$ & 0.31 & 0.95 & 0.91 & 0.80 & 0.82 & 0.74 & 0.76 \\
\hline $\mathrm{Na}(\mathrm{g})$ & 0.29 & 0.19 & 0.20 & 0.31 & 0.32 & 0.24 & 0.22 \\
\hline $\mathrm{K} \quad(\mathrm{g})$ & 0.91 & 0.32 & 0.30 & 0.59 & 0.64 & 0.43 & 0.36 \\
\hline $\mathrm{Fe}(\mathrm{g})$ & 0.016 & 0.062 & 0.061 & 0.051 & 0.046 & 0.058 & 0.057 \\
\hline $\mathrm{Zn}(\mathrm{mg})$ & 5.38 & 23.41 & 24.51 & 21.37 & 22.86 & 20.79 & 20.80 \\
\hline $\mathrm{Mn}(\mathrm{mg})$ & 6.66 & 25.29 & 26.78 & 24.66 & 24.39 & 22.87 & 23.05 \\
\hline \multicolumn{8}{|l|}{ Vitamins } \\
\hline Vitamin A (I.U.) & 350 & 150 & 170 & $<100$ & $<100$ & $<100$ & $<100$ \\
\hline $\mathrm{E}(\mathrm{mg})$ & 8. 33 & 20.13 & 26.04 & 20.4 & 21.4 & 17.6 & 18.8 \\
\hline $\mathrm{B}_{1}(\mathrm{mg})$ & 1.83 & 1.10 & 0.60 & 1.00 & 1.10 & 0.31 & 0.28 \\
\hline $\mathrm{B}_{2}(\mathrm{mg})$ & 1.15 & 2.17 & 1.16 & 1.46 & 1.14 & 1.57 & 1.18 \\
\hline $\mathrm{B}_{12}(\mu \mathrm{g})$ & 3.7 & 730 & 380 & 460 & 320 & 450 & 350 \\
\hline Folic acid (mg) & 0.04 & 0.40 & 0.26 & 0.65 & 0.52 & 0.78 & 0.64 \\
\hline
\end{tabular}

Each constituent in the diet or feces was represented as content in $100 \mathrm{~g}$ of dry matter.

*; Numerals in parentheses show sampling time. 
灯後の約 4 時間の間にピークが現われる傾向が認められ た。このパターンにも加秢に伴う変化が認められ， 5 週 齢から 10 週齢にかけては暗期においても旺盛な coprophagy が観察されたが， 30 週路以降では明暗期ともに coprophagy は低減し，特に暗期において顕著であった (Fig. 1)。

翼の成分を飼料のそれと比べると (Table 2), いずれ の週齢においても粗蛋白質, 粗脂肪および可溶性無窒素 物は飼料の值のそれぞれ $69 〜 89 \% ， 42 〜 48 \%$ および70〜 $76 \%$ 程度であった。逆に粗灰分之粗䄉維は約 $3 \sim 4$ 倍量 に增加していた。 $\mathrm{Na}$ と $\mathrm{K}$ を除いた䔬中の無機質は飼料 の約 $3 \sim 4$ 倍の值に達していた。糞中の $\mathrm{Na}$ と $\mathrm{K}$ の量 は, 飼料の值のそれぞれ 66 110, 33 70\% 程度であっ た。ビタミンの内, ビタミン A は筫中では飼料の $50 \%$ 末満に減少しており,ビタミン $\mathrm{E}$ 飼料の $2 \sim 3$ 倍の 值に增加していた。ビタミン $\mathrm{B}_{1}$ および $\mathrm{B}_{2}$ は飼料の值 と比べて大きな差異はなかった。ビタミン $\mathrm{B}_{12}$ は飼料の 值に対し約100 200倍, 葉酸は約 $6 \sim 20$ 倍量に増加して いた。26〜30週㱓マウスの7〜11時に採取した霬中ビタ ミン $\mathrm{B}_{1}, \mathrm{~B}_{2}, \mathrm{~B}_{12}$ および葉酸の值は $19 \sim 23$ 時の值より 54〜92\% 程度大きかったが，48〜52 週秢と 100〜104 週 龄においては時刻間での差が縮小する傾向にあった。

著者らは, マウスの coprophagy について検討を重ね ているが，生涯を通じた推移についても知る必要がある と考えて今回の実験を行った。その結果, 成長期におい ては明期・暗期を通じて旺盛な coprophagy が観察され たが，加齢に伴って coprophagy は低減する傾向を示 し，特に暗期においては著るしかった。一方，糞の成分 ではビタミン $\mathrm{B}_{12}$ と葉酸が高濃度に含まれていた。両ビ タミンを含め, 他の糞中の成分值に 30 週秢から 104 週齢 にかけて著るしい変動はなかった。

以上のととから, マウスの coprophagy の頻度は成長 や老化の過程における栄養要求に基づいて変化すること が示唆された。成長の著るしい $4 \sim 10$ 週龄にかけて coprophagy の六進が認められたが，その原因について は, 他動物種での長期間に亘る coprophagy の成績が無 いことああって, 不明である。しかしながら，その背景 に成長ホルモンのような因子が関与しているのか否か興
味が持たれるところであり，今後検討すべき課題と考え ている。

\section{要約}

ICR 系マウスにおける coprophagy の, 成長・加㱓に 伴う変化を哺乳中から 104 週秢にかけて調へた。哺乳仔 では自律的に排粪し始めた $2 \sim 3$ 日後の17〜18日齢頃に coprophagy が認められた。 $5 \sim 6$ 週秢では 1 日 1 匹平 均約13個の䔬を摄取しており，以後加齢とともに漸減し 78 週および 104 週齢では, それぞれ 2.1 個と 1.5 個とな った。coprophagy の日内発現パターンにあ週齢によっ て変化が認められ，成長期では明暗期ともに旺盛な coprophagy が観察されたが，30 週齢以降では両期の, 特に暗期における低減が著るしかった。糞中にはビタミ ン $\mathrm{B}_{12}$ と葉酸が高濃度に検出された。以上のととから, マウスの coprophagy の頻度は, 成長や老化の過程に打 ける栄養要求に基づいて変化するととが示唆された。

終りに臨み, 御指導, 御校閲下さいました(財)残留農薬 研究所 毒性部長 白須泰彦博士に深謝致します。終始 御援助をいただいたオリエンタル醉母工業株式会社 北 村佐三郎博士に深謝致します。

\section{文献}

[ 1 ] Barnes, R.H. (1962). Nutr. Rev., 20, 289-291.

[2] Daft, F. S., McDaniel, E. G., Herman, L. G., Romine, M.K., and Hegner, J.R. (1963). Federation proc., 22, 129-133.

［3］海老野耕一・諏訪富男・桑原吉史・斎藤 徹・高橋和明 (1986). 実験動物, 35, 381-386.

[4] Huang, T. C., Urich, H. E., and McCay, C. M. (1954). J. Nutr., 54, 621-630.

[5] Jilge, B. (1982). Laboratory Animals., 16, 7-11.

[6] Neale, R.J. (1982). Laboratory Animals., 16, 204 $-207$.

[7] Takahashi, K.W., Ebino, K.Y., Saito, T.R., and Imamichi, T. (1985). Zool. Sci., 2, 249-255.

[8 ] Takahashi, K.W., Saito, T.R., Suzuki, W., Katsuyama, M., Sakuma, S., Tauchi, K., Kawanishi, H., and Imamichi, T. (1983). Zool. Mag., 92, 397-401.

[9] Thacker, E.J., and Brandt, C.S. (1955). J. Nutr., 55, 375-386. 